\title{
The Success of Pohang Iron and Steel Co. Ltd. (PO SCO):Perfecting Internal and External Incentive
}

\author{
KIM, JUNKI \\ Professor of Graduate School of Public Administration \\ Seoul National University
}

\section{Abstract}

We examine POSCO's success based on the internal and external managerial incentive structure. By internal incentive, we mean institutional foundation under which the interaction between the principal (the government) and the agents (the managers) takes place. This involves examining the political economy of state intervention and how the state employed credible policies intended to end 'politicized' relationship with state-owned enterprises (SOEs). External incentive structure relates to various exogenous market forces that discipline managers and owners in terms of corporate performance. Combined, they determine the extent to which SOEs face 'hardened budget constraints' and in the case of POSCO, the state was able to enforce credible policies that hardened the budget constraint.

\section{Introduction}

Government-run enterprises in the iron and steel industry have meant certain failures, as evidenced by ventures in Brazil (Fisher (1988)). Britain (Vickers and Yarrow (1989)), India (Etienne (1992), and Turkey (Duruiz (1992) and Szyhowicz (1991)). State-owned steelmakers have suffered from gross mismanagement, lack 
of market-based incentives, and frequent political interventions which resulted in substantial economic losses (Qian and Duncan (1993)). Despite the worldwide phenomenon (Hogan (1994)), Pohang Iron and Steel Company Ltd. (POSCO), a state - owned enterprise (SOE) in Korea, has emerged as a legendary success (Oh Yeon Cheon (1993)). In a short span of 25 years, POSCO became the world's second larg. est producer of steel, boasting to have one of the lowest cost steel making facilities in the world. Based on the World Steel Dynamics' 1992 survey of 176 integrated steel plants, POSCO's Kwangyang and Pohang plants are ranked the second and third lowest cost plants, respectively. At the same time, POSCO has remained solidly profitable since making profits of $\$ 11$ million in its first year of commercial operation in 1973 despite deteriorating market conditions of the 1970's and 1980's. Riding on its success, POSCO was partially privatized in 1988 through a broad-based ownership scheme.

What factors contributed to the success of POSCO despite its status as a government-owned enterprise? Building upon the work done by Oh (1993); we seek to explain POSCO's success based on internal and external incentive structure facing its managers. By internal incentive, we mean institutional foundation under which the interaction between the principal (the government) and the agents (the managers) takes place. In particular, we look at how the state regulatory regime reinforced 'hard budget constraints' on POSCO.")

This involves examining the political economy of state intervention and how the state employed credible policies intended to end 'politicized' and 'bureaucratized' relationship with SOEs. External incentive structure relates to the introduction of various market forces that discipline managers in terms of corporate performance. Combined, they determine the power of managerial incentive and thus the level of performance of SOEs. We seek to explain POSCO's productive and dynamic efficiency based on these criteria.

In Section 2, we examine POSCO's success in detail by looking at its past capacity expansion and the cost structure. We find that relatively high labor productivity, low energy and material costs, and low construction costs contributed to its competitive position in the global market. Our main analysis of the institutional structure under which POSCO has been operating is covered in Section 3. We find that "hard

1) This involves making SOEs subject to similar operating conditions as private firms face. 
budget constraint' imposed on POSCO, the competitive product market, relatively 'disciplinarian' SOE policies of the Korean government, and ambitious capital investment programs propelled POSCO to the global leadership in the steel market. Heavy investments in human resources, autonomy from the state, and strong corporate leadership were company-specific factors working in POSCO's favor. In addition, the privatization process of POSCO and its influence on managerial incentive are analyzed in Section 4. We find that the unique features of the privatization scheme used in Korea, namely the broad-based ownership plan and non-transfer of control rights from the state, as well as limited shareholders' rights, prevented POSCO from reaping the full benefits associated with the ownership change. It is followed by conclusions.

\section{Performance Analysis}

POSCO's first commercial steel making facility became operational in 1973 with an annual capacity of 1.03 million metric tonnes (MT). Over the last two decades, POSCO has invested over 18 trillion Won ( $\$ 17.8$ billion) on its plant and equipment, which brought its production level to the current 23. 4 million TPY (tonne per year) in 1995. POSCO has two facilities, one located in Pohang and the other in Kwangyang. The Pohang mill has a 9.1 million TPY capacity. The more modern Kwangyang mill was completed in 1993 with a 11.4 million TPY capacity. ${ }^{2)}$

Its production process is fully automated and thus yields a higher productivity. It is expected that when the expansion plan at the Kwangyang mill is completed in 1998, POSCO's production will rise to 28 million tons, surpassing Nippon Steel as the largest steel producer in the world (POSCO (1996)).

According to Paine Webber (1993), POSCO's operating costs.3. remain among the lowest in the world despite the high depreciation expenditures. Figure 1 shows that POSCO's operating costs were competitive to those of rivals in most categories in 1993. The result was similar in 1988. In analyzing the sources of its structural competitiveness in terms of the composition of production costs, we find the following:

- Aided by low unit labor costs and improving labor productivity, POSCO's

2) Later, POSCO installed an additional 1.5 million TPY capacity.

3) This figure does not include depreciation, interest, and local taxes. 
labor cost per tonne of cold-rolled coil produced was $\$ 60$ lower than those of Japanese and the US counterparts;

- High plant utilization rates," often exceeding 100 percent compared to the low 70 's for the Japanese integrated steel makers and the low 60 's for the US manufacturers, enabled POSCO to reduce unit fixed costs;

- A high product yield rate, measured by the yield to finished product, enabled POSCO to ship more products out. Heavy investments in human resources training and quality control management enabled POSCO to improve its product quality and eventually move into high margin products;

- Substantial savings in raw material costs were achieved through POSCO's equity investments in foreign coal and iron ore mines and competitive long-term contracts with energy suppliers; ${ }^{5)}$

- All phases of construction were completed ahead of the schedule, enabling POSCO to start commercial operation of plants earlier than expected. This gave POSCO an early advantage:the cost for the Pohang plant came to $\$ 422$ per tonne and for Kwangyang it was $\$ 808$ per tonne in current dollar terms, ${ }^{6}$ while during the similar period, construction costs for many integrated plants in Japan and Europe stood at over $\$ 1,000$ per tonne.")

As a result, POSCO's total operating cost per tonne of cold-rolled coil before depreciation and interest expenses was $\$ 100$ to $\$ 120$ lower than its competitors. The cost differential would have been higher if POSCO's actual capacity utilization rate of over 100 percent was used, rather than the 90 percent assumed in Figure 1.8) Taking exchange rate fluctuations into consideration, we still find that unit costs continued to improve in Won."

4) Note that the cost curve is estimated by assuming the noted capacity utilization rates for the most cos -efficient integrated plant in each nation.

5) Part of fuel cost is subsidized through a financial package assembled for the domestic coal industry. Large savings were achieved through long - term contracts and equity investment.

6) This figure refers to costs determined at the end of the project completion. Refer to Figure 1 for construction cost per tonne throughout the period.

7) The following comparable figures are available regarding the unit construction cost:China Steel of Taiwan (1.15 million TPY capacity) for $\$ 857$ and China's Bausan Steel for $\$ 1533$. These are plants constructed in the late 1980's and early 1990's.

8) Note that capacity utilization above 100 percent of design capacity is called "capacity stretching" (Dahlman and Westphal (1982)).

9) The rate, measured at the end of the period by the Bank of Korea, actually appreciated over the period from 890 Won per US $\$$ in 1985 to 808 in 1993. 
Figure 1: Cost of Producing a Metric Tonne of Cold-Rolled Coil in the Most Efficient Integrated Steel Firm in Each Nation (1993)

\begin{tabular}{|l|l|l|l|l|l|l|}
\hline \multicolumn{1}{|c|}{ Item } & US & Germany & Japan & Brazil & $\begin{array}{c}\text { Korea } \\
\text { Minimill }\end{array}$ & POSCO \\
\hline Operating cost & 153 & 175 & 153 & 74 & 99 & 90 \\
Labor & 67 & 69 & 51 & 40 & & 53 \\
Iron Ore & 42 & 38 & 33 & 47 & 150 & 42 \\
Scrap & 38 & 44 & 36 & 56 & & 41 \\
Coal or Coke & 172 & 179 & 201 & 186 & 170 & 158 \\
Misc. & 472 & 505 & 474 & 403 & 419 & 384 \\
\hline Total Operating Cost & 26 & 42 & 76 & 83 & 100 & 112 \\
\hline Depreciation & 15 & 11 & 22 & 52 & 25 & 15 \\
\hline Interest & 513 & 558 & 572 & 538 & 544 & 511 \\
\hline Total Pre-tax Cost & & & & & & \\
\hline Addendum: Input Prices & 30 & 33 & 30 & 8 & 11 & 12 \\
Labor cost( \$ /man-hour) & & & & & & \\
\hline Efficiency Measures & 5.1 & 5.3 & 5.1 & 9.2 & 9 & 7.5 \\
Man-hours per ton & 90 & 90 & 90 & 90 & 100 & 90 \\
Capacity utilization & & & & & na & \\
\hline Cost through process & 108 & 129 & 104 & 119 & & 101 \\
Coke & 146 & 159 & 129 & 122 & & 120 \\
Blast furnace & 205 & 214 & 188 & 185 & & 172 \\
Liquid Steel & 248 & 256 & 223 & 217 & & 205 \\
Slabs & 319 & 341 & 301 & 277 & & 257 \\
Hot mill+Packing & 424 & 443 & 399 & 363 & & 329 \\
Cold mill and overhead & 59 & 56 & 58 & 63 & & 52 \\
\hline Costs from process to process & & 42 & 35 & 33 & & 33 \\
BF to liquid steel & 71 & 85 & 79 & 60 & & 52 \\
Slab to liquid steel & 105 & 105 & 97 & 86 & & 72 \\
Slabs to hot rolled steel & & & & & na & \\
HR to cold rolled steel & & & & & \\
\hline
\end{tabular}

Source:World Steel Dynamics(1993). na means not available. 
In terms of profitability, POSCO's EBITD (Earnings Before Income, Taxes, Interest and Depreciation expenses) to sales ${ }^{10)}$ remains solid around 40 percent since the early 1980's, some 20 percent higher than most integrated steel manufacturers similar in size to POSCO (Paine Webber (1991)). Labor productivity, measured in man - hours per tonne shipped, continues to improve. Between 1973 and 1989, the man -hours per tonne of steel shipped decreased from 14.1 to 7.1, an increase of close to 100 percent. This tops the 47 percent and 45 percent improvements charted by similarly sized integrated mills in Japan and the US, respectively, during the same period. In terms of moving up to high margin products, the proportion that cold-rolled coil and coated sheet took increased to 22 percent of total shipments in $1990 \mathrm{com}$ pared to 8 percent in 1982. POSCO also made a successful transition from initially concentrating on low - value added products to the production of high margin products when other developing nations entered into the lower end market.

\section{The Analytical Framework:The Internal and External Incen- tives}

Although ownership matters in many respects, the importance of balancing internal and external incentives of SOEs under the government ownership has been under-emphasized in the literature with the exception of few (Muir and Saba (1995)). This is because most conventional SOE sector reform programs other than privatization schemes are based on incremental approaches which inhibit them from taking measures that simultaneously affect internal and external incentive facing SOEs. In contrast to privatization, although 'conventional' SOE sector reform attempts aimed at changing managerial incentive structure may not fundamentally resolve 'soft budget constraint' problems associated SOEs, these programs should improve SOE sector efficiency through formalizing the relationship between the state and SOEs and through the introduction of market forces in the interim. Thus, these reform programs should be used when governments are faced with technical or political constraints in privatizing SOEs but seek to improve their efficiency in the meantime.

Internal incentive structure refers to the design of corporate governance and in-

10) The ratio is a measure of operating profitability before financial expenses. 
ternal managerial incentive programs that seek to realign managerial incentive with the principal's goals of profit maximization in the case of private firms and welfare maximization in the case of SOEs. Although typical internal incentive structure describes the interaction among corporate players including shareholders, boards of directors, and appointed executive, unique $\mathrm{SOE}$-specific institutional structure necessitates the examination of other factors such as the state's SOE policy and the use of performance contracts. The examination of the SOE policy is important as it establishes the broad tone of the extent of 'soft budget constraints' facing SOE managers and hence reveals the extent to which SOE managers enjoy 'easy subsidies' from the state. As developing nations have often relied on selective industrial policies, otherwise known as selecting 'winners' in strategic industries with high forward and backward linkages (Rodrik (1992)), the nature of the state's intervention in the marketplace also provides clues to the likely policy-orientation of the state towards its SOE sector.

External incentives refer to various forms of market-based forces that ensure economic efficiency and accountability within the SOE sector. According to Muir and Saba (1995), they take the form of product market competition, competitive capital markets, both equity and debt markets that monitors SOEs' performance, external managerial labor market, corporation's legal obligations, and bankruptcies. We primarily consider the role of product market competition and technological development that ensured technical efficiency in POSCO. ${ }^{11}$

Note that these internal and external incentive structure must be simultaneously combined to minimize the extent to which SOE managers face 'soft budget constraints' and must be sustainable in the long run. This can only be achieved with credible government commitment to reform. Credible SOE policies require three factors:terminating state subsidies and state (political) intervention, guaranteeing autonorny to SOE managers, and conducting structural adjustment policies that eliminates barriers to entry. Countries that have adopted these measures in separate stages of SOE sector reform have all experienced a lack of productivity improvements (World Bank (1996)). Each measure alone can not alter the fundamental incentive schemes facing SOE managers and thus serious reform minded states should

11) Note that this has an added advantage of providing a benchmark performance figure where SOEs' productive efficiency can be directly compared with that of their counterparts in the private sector. 
- resort to a comprehensive approach of adopting all these measures. We argue both these measures were implemented simultaneously in POSCO.

\subsection{Internal Incentive and POSCO}

The question of SOE sector efficiency largely depends on the attitude of the state towards hardening SOE sector budget constraints. This, in turn, depends on the extent of government intervention and the quality of such intervention. According to Rodrik (1992), state intervention works differently in two kinds of states:autonomous and subordinate states where the former refers to a regulatory regime based on pre-commitment of its future actions and thus acts as a stackelberg leader vis$\mathrm{a}-$ vis the private sector and the latter a follower vis $-\mathrm{a}-$ vis the private sector. ${ }^{(2)}$ He concludes that state intervention in subordinate state is subject to 'capture' by politically motivated interest groups and results in sending wrong signals to both the SOE and private sectors. It implies that the SOE sector efficiency depends on the ability of the state to insulate itself from special interest groups that seek to maximize rent seeking behavior.

Governments can influence the working of the SOE sector by controlling public subsidies, pricing and investment decisions, and personnel policies. The frequency of the government intervention determines the relationship between the state and SOEs, and the extent of 'soft budget constraints' (Kornai (1979)). 'Soft budget constraint' refers to the extent to which SOEs and their managers, faced with non-existent threats of bankruptcy and subsequent government bail-out, fail to pay close attention to the viability of their operation. Because of frequent political and bureaucratic intervention, SOE managers do not have proper incentive to minimize costs and thus inappropriate uses of internal and external funds could ensue.

In comparison to other developing nations, the Korean government employed more competitive and commercial approach in its relationship with the SOE sector (Song (1989), Jones and Sakong (1980)). With the reform of SOE sector in 1983 and 1989, the government began to promote financial independence of SOEs by making it difficult to obtain subsidies. In addition, the government linked managerial autonomy to financial performance-profitable units were given more freedom over person-

12) This roughly corresponds to Myrdal's (1968) "hard" and "soft" states. 
nel and other aspects of operation. Through several phases of rationalization and privatization, the state returned those firms to the private sector to concentrate on other cases of market failures (EPB (1988), Song (1989)). ${ }^{13)}$ This led the government to impose a "disciplinarian" policy, under which budget constraints" are hardened by tying subsidies and credit availability to the financial performance of SOEs. The government's SOE policy is illustrated in cases of Korea Tungsten Corporation and Daehan Coal Mining Corporation. Prompted by heavy losses in these enterprises and a cyclical downturn, the government decided to reduce operational divisions and cut production lines rather than continue subsidizing their operations.

Under this background, the state did the following to harden POSCO's budget constraint,:

- the government incorporated POSCO as a commercial concern, enabling POSCO to avoid cumbersome bureaucratic guidelines and formal regulations. In addition, the state categorized POSCO as a government-funded enterprise, rather than a government-invested enterprise, which meant that less government intervention and regulation;

- after providing its initial investment and capital injections in the early 1970's, the state substantially reduced its direct contributions to POSCO. In response, POSCO relied on domestic and foreign commercial loans, which were based on economic merits; ${ }^{15)}$

- since its operation in 1973, POSCO was subject to corporate taxes. This raised the effective rate of return required to demonstrate the firm's competitiveness to the investors (Jenkins (1995));

- because of its importance to steel consuming industries that relied on exports for much of their sales, the government encouraged POSCO to maintain competitive domestic prices and at the same time instituted mechanisms to deter POSCO from exercising monopolistic power. The government accomplished this through the passage of Anti-Monopoly Act which provided it with an authority to monitor

13) Se Atkinson and Stiglitz (1980), to better understand classic government interventions in the economy, including cases of externalities, public goods, and monopolies.

14) Budget constraints are hardened by making it difficult for SOEs to obtain government funding and by removing senior management in firms with performance problems.

15) Even when POSCO experienced short - term cash-flow prablems, the government did not hand out subsidies, but rather relied on the Korean Development Bank for loans through the Industry Structural Adjustment Loan Program. 
business ethics and diversification activities of POSCO and 30 largest conglomerates, as defined by sales. As a result, the domestic price for cold-rolled coils only went up by 4.2 percent in the 1980's during which the world market experienced an increase of 26 percent;

- after being granted with a quasi-private firm status, POSCO was faced the threat of managerial takeover. Because of Korea's substantial managerial labor pool, the government often punished non-performing managers by threatening to replace senior management. ${ }^{(6)}$

There are other institutional problems associated with the operation of typical SOEs in developing nations. Problems include the multiplicity and ambiguity of corporate goals, limited autonomy, extensive political and bureaucratic interference, and limited managerial incentives. Figure 2 summarizes the classic SOE sector symptoms and how POSCO dealt with each issue. Since hardening of the budget constraint has been already discussed, we start our analysis with the multiple goal setting environment in SOEs.

One classic argument explaining the ineffectiveness of SOEs has been put forward by economists including Aharoni and Vernon (1981), Jones and Mason (1982), and Vickers and Yarrow (1988). It is based on the problem posed by the multiplicity and ambiguity of SOE corporate goals, which tend to confuse managers. By definition, an SOE is an institution whose mission is to employ private sector techniques to achieve social objectives dictated by politicians, interest groups, and bureaucrats. In most cases, the conflicting message of profit maximization and vote maximization through subsidized pricing, however, pose difficulties in defining corporate goals. As mentioned previously, the government created POSCO as a commercial entity, not as a government enterprise. ${ }^{17)}$ This reduced avenues through which bureaucrats can impose social objectives. In addition, 'disciplinarian' industrial and SOE policies essentially limited the imposition of socially desired and economically costly goals such as over-employment.

16) This was shown in 1993 when POSCO's twelve directors were replaced during "a Friday massacre," engineered by the government, who were unhappy with POSCO's internal power struggles.

17) See Tirole (1993) on the expropriation o managerial investments. 
Figure 2:POSCO's Response to Overcoming Traditional SOE Problems

\begin{tabular}{|c|c|c|}
\hline Types of PE Sector Barriers & Traditional Symptoms & How the State and POSCO Responded \\
\hline Soft budget constraint & $\begin{array}{l}\text { Little discipline over } \\
\text { its cash-flow and low } \\
\text { managerial incentives }\end{array}$ & $\begin{array}{l}\text { - Competitive industrial and SOE policy } \\
\text { - Create POSCO as a commercial con- } \\
\text { cern:a symbolic gesture to limit ties } \\
\text { with the government } \\
\text { - Clear target goal of reaching the effi- } \\
\text { ciency level of Japanese firms } \\
\text { - Invest heavily in human resources de- } \\
\text { velopment:extensive in-house and } \\
\text { overseas training } \\
\text { - Partial privatization:more efficient pri- } \\
\text { vate monitoring and less government } \\
\text { monitoring }\end{array}$ \\
\hline $\begin{array}{l}\text { Multiplicity and ambi- } \\
\text { guity of corporate } \\
\text { goals }\end{array}$ & $\begin{array}{l}\text { Confusion of manage- } \\
\text { rial objectives and } \\
\text { managerial } \\
\text { disincentives }\end{array}$ & $\begin{array}{l}\text { - Limit imposition of political and social } \\
\text { goals by specifying commercial goals } \\
\text { in the mission statement } \\
\text { - Limit intervention by bureaucrats:for- } \\
\text { malizing ties with government } \\
\text { - Use political constituents as a barrier } \\
\text { for state intervention }\end{array}$ \\
\hline $\begin{array}{l}\text { Limited autonomy and } \\
\text { high political and bu- } \\
\text { reaucratic interference }\end{array}$ & $\begin{array}{l}\text { Motivational and hier- } \\
\text { archical problem }\end{array}$ & $\begin{array}{l}\text { - Build political support from the top of } \\
\text { the political ladder to gain autonomy } \\
\text { - Reduce dependence on government } \\
\text { through financial independence } \\
\text { - "Capture" regulators and bureaucrats } \\
\text { at large to pursue favorable policies }\end{array}$ \\
\hline $\begin{array}{l}\text { Limited reward } \\
\text { system and low mana- } \\
\text { gerial incentives }\end{array}$ & $\begin{array}{l}\text { Managerial incentive } \\
\text { problem and excessive } \\
\text { risk-aversion }\end{array}$ & $\begin{array}{l}\text { - Allow pay structure equaling the best } \\
\text { of the private sector and institute } \\
\text { merit pay system } \\
\text { - Severe penalties for corruption and } \\
\text { managerial slack, coupled with strong } \\
\text { internal audit team } \\
\text { - Transfer of managerial autonomy to } \\
\text { individual plants within POSCO } \\
\text { Attach the success of the firm to pro- } \\
\text { vision of non-pecuniary benefits: } \\
\text { housing, ESOP, schooling and work } \\
\text { place environment }\end{array}$ \\
\hline
\end{tabular}




\begin{tabular}{|c|c|c|}
\hline $\begin{array}{l}\text { Internal (Firm) level } \\
\text { Reform }\end{array}$ & $\begin{array}{l}\text { - Public Entrepre- } \\
\text { neurship } \\
\text { (Ramamurti } \\
(1987)) \\
\text { - Power of labor } \\
\text { union } \\
\text { - Corporate culture } \\
\text { - Relationship with } \\
\text { suppliers }\end{array}$ & $\begin{array}{l}\text { - Excellent top leadership largely moti- } \\
\text { vated by benevolent patriotism and ex- } \\
\text { pansion of plants (Kwack (1993) and } \\
\text { Paine Webber (1987)) } \\
\text { - Weak and prevented in the early stage } \\
\text { by paying top wages (D'Costa (1994) } \\
\text { and Paine Webber (1984)) } \\
\text { - Committed managers and workers } \\
\text { through well established corporate cul- } \\
\text { ture, with emphasis on serving the na- } \\
\text { tion (Kwack (1993)) } \\
\text { - Developing steady and long-term rela- } \\
\text { tionship through equity investments } \\
\text { (POSCO (1988)) }\end{array}$ \\
\hline
\end{tabular}

Source:Adapted from Ramamurti(1986)

Limited managerial autonomy arising from frequent political and bureaucratic intervention is another common feature of SOEs, especially those with social importance and substantial market power (Mason (1958) and Aharoni (1986)). Often managerial autonomy and managerial accountability are not specified in procedural regulation and establishment Acts, and therefore senior management encounter difficulties in establishing corporate goals. As a result, managerial motivation and organizational hierarchical problems often surface (Ramamurti (1987)). In the case of POSCO, however, autonomy was granted largely for political reasons and were reinforced by its superior financial performance. As the Shleifer and Vishny's (1994) privatization model suggests, by taking away the need for government subsidies, ${ }^{18)}$ POSCO managed to avoid the imposition of government goals, which often differ from managerial goals.

POSCO sustained internal managerial incentives by implementing "a carrot and stick" policy. This was achieved through implementing a strict merit-based personnel policy, which protected it from outside influences that often affected other Korean SOEs. At the same time, POSCO instituted pay and working conditions equal to

18) In their model, subsidies were for excess employment of labor. Subsidies given to SOEs should be viewed as the loss of leverage on the part of SOEs when bargaining over the level of subsidies with governments. 
the best standard found in the public and private sectors (Paine Webber (1985)). ${ }^{19}$ ) Managerial autonomy allowed POSCO to fire workers for performance deficiencies more easily than other SOEs. In addition, many economists (Blasi (1989) and Guasch (1995)) believe that by giving managers and workers a sense of mission for their work, namely the production of competitively priced steel products critical to the export-driven economy, POSCO was able to maintain a high level of morale (Kwack (1993) and Paine Webber (1991)).

\subsection{External Incentive and POSCO}

Perhaps the most important exogenous factor impacting the performance of SOEs is the overall degree of product market competition that they face. Contestable market theory tells us that full vigor of competition and freedom of entry and exit are important determinants of corporate performance. In addition, product market competition provides important benchmark performance figures and, thus, delineates information asymmetry problems existing between the principal and the agent.

Product competition in the iron and steel product market played an important role in cutting down POSCO's managerial slack. Over - capacity in the world market and oil shocks in the early 80's led to cut-throat competition among surviving world steel makers and POSCO was no exception (Barnett and Crandall (1986)). Especially, competition from efficient mini-mills and other developing nations including China and Brazil disciplined POSCO and forced its efforts on increasing dynamic efficiency of the firm. Because of its reliance on the export market, cost-efficiency became the only way to survive in the industry. At the same time, import barriers erected in the 1970's to protect the industry were eliminated due to pressures from its trading partners, keeping POSCO on its toes (KDI (1991)).

POSCO's global competitiveness came in the midst of continuous expansion of the world production capacity. Thus, technological development is important in analyzing POSCO's structural competitiveness. Specifically, the degree to which new products and process technology were adopted and the level to which POSCO expended

19) In addition to paying a higher wage rate, almost two times the private sector rate (Paine Webber (1985)), the difference in starting salary and pay scale between college and technical school graduates was narrower than most private firms, where there was at least 15 to 30 percent difference between the two groups in their initial pay. 
its resources on $R \& D$ are key determinants. Technological investments, including those on continuouis casters, factory automation, and new plant construction made POSCO one of the most technologically advanced steel producers in the world. During the expansion process, productivity increased in all activities of operation, as evidenced in Figure 1. Rather than relying on cheap labor to gain the competitive edge, POSCO shifted production from the low-end market to the high-end market and its heavy investments in modern machinery boosted POSCO's productivity level.

To strengthen its technological capacity, technological transfer measures and local component requirements were included in contracts with foreign primary suppliers. POSCO and local contractors also actively took part in the construction and installation of plant and equipment, which enabled them to gain technological know - how. ${ }^{20}$ POSCO's technological progression is described by Enos and Park (1988), who documented improvements in equipment design and operating procedures. Assimilation of technology was further facilitated by POSCO's commitment to R\&D ${ }^{21}$ ) and the establishment of the Pohang Institute of Science and other technology and research centers.

\section{Partial Privatization and Internal Incentive}

Vickers and Yarrow (1988) assert that privatization affects the performance of SOEs through changes in the owner's objective function, which, in turn, alter the managerial incentive structure. In addition, privatization improves the monitoring mechanism on SOEs through the role played by stock market participants because individual shareholders, fund managers, other institutional investors, brokers, and analysts have vested interest in obtaining precise information on future prospects of the company in question. Retiring shares from stock markets through nationalization, however, tends to replace stock market monitoring with the government ministerial or political monitoring of SOEs, which many argue is likely to do a poor job (Caves (1991) and Jones (1989)). In addition, partial and full government

20) This was obtained through interviews conducted in January 1994 with POSCO management.

21) R\&D investment accounted ten percent of profits since 1983, a percentage considered high among steel companies. As a result, royalty payments for construction and operating technology declined 6 . 5 percent, 17.2 percent, and 100 percent, respectively in the second, third, and fourth stages of the Pohang mill expansion (Enos and Park (1989)). 
ownership of shares effectively removes the markets for corporate control, which supposedly provides incentives for senior managers to become more efficient (Bbos (1992)):22)

As Figure 3 illustrates, partial privatization of POSCO in 1988 added the private sector monitoring as a key feature of the institutional structure involving POSCO. It increased the availability of managerial information on POSCO through listing its shares in the stock market. The Stock price and other relevant managerial information arising from the requirement to report such information to the stock market provides an important incentive for managers as they act as benchmark comparison data.

Figure 3: Institutional Structure involving POSCO

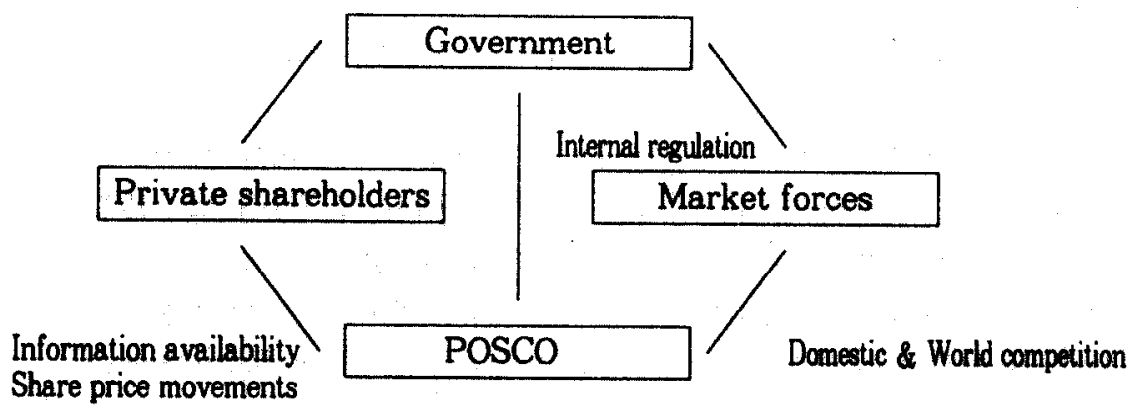

Source: Om Conception

There are, however, several cautionary notes to POSCO's privatization. First, because of the government's reliance on the internal regulation of strategic indus-

22) There is, however, no consensus on the efficiency of stock markets to provide a fundamental measure of a firm's long - term viability. In addition, the effectiveness of markets for corporate takeovers has long been suspected (Grossman and Hart (1980). This is especially true in cases where governments maintain a veto clause similar to "the Golden Share rule" in the UK. In addition, although more broad implementation policies are required, political takeovers of SOEs are possible, and public managers do get fired. 
tries, ${ }^{23)}$ the government opted for partial privatization of POSCO. ${ }^{24)}$ This enabled the government to retain control right of POSCO and this meant that the benefits arising from the ownership change was somewhat limited. Second, the divestiture of POSCO through a broad-based ownership scheme partially transferred cash-flow rights to a large number of shareholders who were unlikely to exercise the complex shareholder roles required in the modern corporate governance structure (Shleifer and Vishny (1980)). The dispersed ownership structure poses several disadvantages, particularly in monitoring. Due to free-rider problems and transaction costs involved in monitoring, the dispersed ownership structure is less effective in monitoring of management than ones with concentrated ownership structure. Furthermore, special provisions in the company's articles of association limited the rights of private shareholders to demand management information. ${ }^{25)}$

In addition, concerned with the possible takeover of POSCO by chaebols and foreign investors, the state imposed a restriction on the holding of private shareholders to less than five percent.

Overall, the privatization technique used in POSCO compromised the economic benefits promised by the reform (Shleifer and Vishny (1986 and 1994)). Not only did it lowered the privatization price, but also limited the monitoring role of the stock market participants. In addition, shares were offered to managers and workers as a 'bribe' to win their support for the privatization. The effectiveness of employee stock ownership plan (ESOP), however, has been disputed in the recent literature (Blasi (1988)). Because of the free-rider problem resulting from linking managerial incentives to corporate performance, the ESOP is unlikely to have a major impact on POSCO in the long-run. ${ }^{26)}$

23) Internal regulation refers to the control of SOEs through ownership, while external regulation refers to the control of privatized or private firms through implicit or explicit regulatory contracts. In essence, public ownership of POSCO was not consistent with the government's broad emphasis on the external regulation of firms through market power.

24) Crossman and Hart (1986) distinguished between control rights, whick. determine the rights to make decisions to use assets, and cash flow rights, which give rights to earn benefits (costs) that result from the use of the assets.

25) Similarly, the Act restricted the right to demand representation on the board of directors.

26) Despite the lack of a clear economic rationale by the government regarding the privatization process, it achieved the following objectives:the broad ownership of shares, deepening of the stock market, and increased availability of managerial information on POSCO. 


\section{Conclusions}

The POSCO's success is besed on the state-sponsored competitive industrial and SOE policies that emphasized the firm's long-term competitiveness (Griffin (1991)) and the imposition of a "hard budget constraint". Strategic and managerial autonomy, and market competition also "guided" POSCO to its success. POSCO's experience shows that SOE performance can be improved through internal reforms that 'formalizes' the relationship between the state and the SOE. Improvements in internal corporate governance should be programmed from the view point of increasing long - term adaptability of SOEs to changing market conditions while changes in the external environment, particularly product market competition and other policies that are aimed at increasing managerial responses to 'contestable' market theories, should entail increases in the availability of managerial information. Partial privatization also increased the role of private monitoring but were limited by the measures the government took to protect its control rights.

The applicability of POSCO's model to other nations, however, is highly questionable because of its unorthodox style of management and the unique industrial policy under which it was developed. Unlike Chang and Singh (1993), who portrayed the success of POSCO as an example of the public sector's potential, we view POSCO's success as an exception to the norm and doubt its long-term sustainability. Depoliticized relationship cannot be guaranteed under different regimes and the current structure still leaves rooms for political and bureaucratic intervention.

Based on POSCO's past performance, the Ministry of Finance and Economy announced that POSCO would remain in state hands because of their important contribution to the economy. ${ }^{2 n}$

The government justified the decision by assuming that the transaction costs and the availability of managerial information in the external regulatory setting of POSCO are more problematic than the current format of internal regulation. ${ }^{28)} \mathrm{We}$ feel, however, that this trade-off relationship warrants further studies. If the current literature reveals any truth (Shleifer and Vishny (1994) and Lopez-de-

27) Reuters World Service, February 1994.

28) External regulation involves the regulation of a privatized SOE, while internal regulation involves the continued public ownership of key sectors. 
Silanes (1994)), de-politicization of POSCO through full privatization is critical at this stage of POSCO's corporate development.

\section{Bibliography}

Aharoni, A. (1986), The Evolution and Management of State-Owned Enterprise, Cambridge, MA, Ballinger Publisher. and Raymond Vernon (1981), The State-Owned Enterprise in the Western Economies, New York, NY, St. Martin's Press.

Amsden, A. H. (1989), Asia's Next Giant:South Korea and Late industrialization, New York, N.Y., Oxford University Press.

Atkinson A. B. and J. E. Stiglitz (1980), “A New View on Technological Change, : mimeo, M.I.T.

Atkinson, Anthony and Joseph E. Stiglitz (1987), "Public Sector Pricing and Production," pp. 457-481 in Lectures on Public Economics; McGraw-Hill Book Co., Singapore.

Barnett, D. F. and R. Crandall (1986), Up From the Ashes:The Rise of the Steel Minimill in the United States, Washington D.C., Brookings Institute.

Berle, A. A. and G. Means (1932), The Modern Corporation and Private Property, New York, N.Y., MacMillan.

Berle, Adolf A. and Gardiner Means (1932), The Modern Corporation and Private Property, New York, Macmillan.

Blasi, J. R. (1988), Employee Ownership:Revolution or Ripoff?, Cambridge, MA, Bellinger Publisher.

Chang, H-J and A. Singh(1993), "Public Enterprise in Developing Countries and Economic Efficiency," UNCTAD Review, pp. 45-82.

Cho D. S. (1990), A Study on Chaebols, Seoul, Korea (in Korean).

Chosun Ilbo (1988), "POSCO's success and Chairman Park," October 23, Seoul, Korea (in Korean). Korea (in Korean).

(1995), "rivatization meaning Conglomertization," March 11, Seoul,

Dahlman and Westphal (1982), "Capacity Overstretching," mimeo, New York University.

D'Costa, A. (1994), “State, Steel, and Strength:Structural Competitiveness and Development in South Korea," Journal of Development Studies, vol. 31(1). 


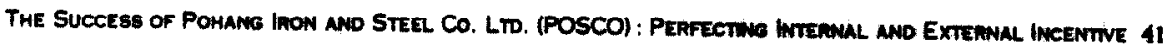

Duruiz, L. (1992), Facing Challenge:Turkish Automobile, Steel, and Clothing Industries' Responses to the Post-Fordist Restructuring, Istanbul.

Enos, J. L and W. H. Park (1988), The Adoption and Diffusion of Imported Technology:The Case of Korea, New York, N.Y., Croom Helm.

Etienne, G. (1992), Asia Crucible:The Steel Industry in China and India, New Delhi, India, Sage.

Fischer, B. (1988), Capital-Intensive in Newly Industrializing Countries:The Case of the Brazilian Automobile and Steel Industries, Tubigen, Germany, Mohr Publisher.

Griffins, James (1991), “A Test of the Free Cash Flow Hypothesis," Review of Economics and Statistics, vol. 70, pp.76-82.

Grossman, S. J. and O. D. Hart, "The Costs and Benefits of ownership:Theory of Vertical and Lateral Integration," Journal of Political Economy, vol. 94(4).

and O. D. Hart (1986), "Takeover Bids, the Free-rider Problem, and the Theory of the Corporation," Bell Journal of Economics, vol. 11 (Spring), pp. $42-64$.

Guasch, J. L. and P. T. Spiller (1995), “Regulation and Private Sector Development in Latin America," The World Bank.

(1995), Lecture Notes on the Public Enterprise Program, Harvard Institute for International Development, Cambridge, MA.

Jenkins, Glenn (1995), "Finance and Taxation," Lecture Notes for the Public Enterprise Program, Harvard Institute for International Development.

Jones, Leroy, and I. Sakong (1980), Government, Business, and Entrepreurship in Economic Development:The Korean Case, Cambridge, MA, Council on East Asian Studies, Harvard University Press.

and E. S. Mason (1980), "The Role of Economic Factors in Determining the Size and Structure of the Public Enterprise Sector in Mixed Economy," Mimeo, Harvard University and Boston University.

(1991), “Performance Evaluation for Public Enterprises," Discussion Paper no. 122, World Bank, Washington, D.C.

Kim, B. W. and W. J. Rho (1982), Korean Public Bureaucracy, Seoul, Korea, Kyobo Publications.

Kim, Il-Sup (1991), "A Study of Effectiveness of Management Performance Evaluation System of Government - Invested Enterprises in Korea:With Special Emphasis on Quantitative Evaluation Index Framework," Unpublished Dissertation, 
Seoul:Seoul National University.

Kim, Kwanbo (1993), "Impact of the GIE Management Act of 1984 on the Performance of Pubic Enterprises in Korea:Theory and Practices of Public Enterprise Reform," Working Paper, USC.

Kim, Kwang Suk, and M. Roemer (1979), Growth and Structural Transformation, Cambridge, MA, Harvard University Press.

, and L. Westphal (1977), Industrial Policy and Development in Korea, Staff Working Paper no. 263, World Bank, Washington D.C.

Kim, S. (1987), Business Concentration and Government Policy: A Study of Phenomenon of Business Groups in Korea, 1945-85, Doctoral Thesis, Harvard Business School.

Kornai, Janos (1979), The Dilemmas of a Socialist Economy:The Hungarian Experience, The Economic and Social Research Institute.

Kwack, S. (1993), POSCO's Success, Seoul, Korea (in Korean).

Lopez-de-silanes, F.(1994), "Determinants of Privatization Prices," Harvard University mimeo, Harvard Economics Department.

Muir, R. and J. S. Saba, "Improving State Enterprise Performance, Technical Paper no. 306, The World Bank, Washington D.C.

Oh, Yeon Cheon (1993), "POSCO's Success and its Future Strategies," Korea Journal of Policy Studies, Vol. XIII, Graduate School of Public Administration, Seoul National University.

Paine Webber (1984-1993), World Steel Dymamics, New York, N.Y. (1985), POSCO:Korea's Emerging Giant, World Steel Dynamics, New York, N.Y.

Paine Webber (1991), POSCO: Still the Paradigm, New York, N.Y. POSCO (1963-96), Annual Reports, Pohang, Korea (in Korean). (1979), POSCO' First 10 Years, Pohang, Korea (in Korean). (1989), POSCO' First 20 Years, Pohang, Korea (in Korean).

Ramamurti, R. (1986), "Turning Around State-Owned Enterprises:The Role of Contextual Factors and Managerial Actions," Working Paper, Northeastern University.

(1986), "The South Korean System for Performance Evaluation of Public Enterprises," UNDP Working Paper, NY.

(1987), "Controlling State-Owned Enterprises," Public Enterprise, vol. $7(2)$. 
Reuters World Service, February 1994.

Research Institute of Science and Technology (1986), POSCO and Korea's Macroeconomy, Pohang, Korea (in Korean).

Rodrik, Dani (1992), "Political Economy and Development Policy", European Economic Review, vol. 36. Nos.2/3, pp. 329-336.

Shleifer, Andrei and Robert W. Vishny (1988), “Management Ownership and Market Valuation," vol. 20 (January/March), pp. 293-315.

(1986), "Large Shareholders and Corporate Control," Journal of Political Economy, vol. 94(3).

(1994A), "The Politics of Market Socialism," Journal of Economic Perspectives, vol. 8 (2), pp. 165-176.

(1994B), "Politicians and Firms," unpublished paper, Harvard University and The University of Chicago.

Song, Dae-hee (1989), "Management Policy on Korean Public Enterprises," Seoul, Korea:Korea Development Institute (in Korean).

(1991), “Korean Public Enterprise Performance," Seoul, Korea:Korea Development Institute (in Korean).

and M. Song (1992), "Privatization of State-Owned Enterprises through People's Share Ownership Program:Economic Analysis," Korea Development Research vol. 14(2), Seoul, Korea, Korea Development Institute (in Korean).

Spruill, C. R. (1982), Conglomerates and the Evolution of Capitalism, Carbondale, IL., Southern Illinois University Press.

Szyliowicz, J.S. (1991), Politics and Technology and Development in Turkey, MacMillan, London.

Tirole, Jean (1988), The Theory of Industrial Organization, Cambridge, MA, MIT Press.

(1991), "Privatization in Eastern Europe:Incentives and Economics of Transition," in Olivier J. Blanchard and Stanley Fisher, eds., Macroeconomics Annual, MIT Press, Cambridge, MA, by National Bureau of Economic Research.

Vickers, John and George Yarrow (1988), Privatization:An Economic Analysis, chapter 2, pp. 7-44, MIT Press, Cambridge, MA.

(1988), "Regulation of Privatised Firms in Britain," European Economic Review, vol. 32, , pp. 465-472. 
(1988), "Telecommunications," chapter 8, pp. 195-241 in Privatization:An Economic Analysis, MIT Press, Cambridge, MA. World Bank (1987), “Korea:Managing the Industrial Transition,” A World Bank Country Study, Washington D.C.

(1992), Welfare Consequences of Selling Public Enterprises:Case Studies from Chile, Malaysia, Mexico and the U.K., Country Economics Department, Public Sector Management and Private Sector Development Division, Washington, D.C.

(1993), "Subsidies and Directed Credits to Enterprises in Russia:A Strategy for Reform," unpublished paper, Country Operations Division 2, ECA Country Department III, World Bank.

Yonekura, S. (1994), The Japanese Iron and Steel industry, 1850-1990.Continuity and Discontinuity, New York, St. Martin's Press. 